\title{
Modeling a Computer Program for Evaluating the Construction Consulting Bids According to the Iraqi Standard Bidding Documents
}

\author{
Noor A. Ramadhan ${ }^{1, \mathrm{a}^{*}}$ and Sawsan M. Rasheed ${ }^{1, \mathrm{~b}}$ \\ ${ }^{1}$ Civil Engineering Department, University of Baghdad, Baghdad, Iraq \\ an.ramadhan1901m@coeng.uobaghdad.edu.iq.
}

\begin{abstract}
The professional service procurement's plan and process have a major effect on the construction project's success. In the projects of the public sector, the stress between cost and quality is constant. Public authorities are responsible for maximizing value for money while also protecting the quality and performance of the construction project they develop. Issuing the standard bidding documents for consultancy service (SBDCS) was one of many procedures taken by the Iraqi Government represented by the Ministry of Planning to improve the procurement system in Iraq. The SBDCS were designed to acquire high professional services, achieve the economy and efficiency, and give all qualified consultants opportunities to provide service for the Government financed construction projects. In reviewing the reality of SBDCS's application, the inability of the Government's contracting bodies to achieve the desired documents' objectives was observed. Six projects that applied the SBDCS were chosen as case studies in this research. The lack of adequate qualification of the staff assigned to prepare the bidding document was the main reason that hindered the correct application, which led to the delay in the consultants' procurement and contracting process. An evaluation computer program was modeled for the selection of consultants based on the criteria of Iraqi standard bidding documents. The proposed program aims to facilitate the process of consultant selection according to SBDCS.
\end{abstract}

Keywords: Evaluating; consulting's bids; public sector; construction project; computer program; Iraqi standard bidding documents.

\section{Introduction}

A construction Consultancy Services can be defined as an ideological technology based on innovation and knowledge in the field of construction projects' environment. The quality of expert service relies upon sufficient expenses to permit the consultant to allocate appropriately qualified staff for an adequate period. It is significant to create formal techniques for getting consultancy service that aims to encourage the advancement of skills and knowledge that play an important role to improve quality in the public sector's field; therefore, numerous countries start to enhance their consultant procurement plan through enlarging the influence of consultant acquisition regulations [1].

In Iraq, the Ministry of Planning commenced its efforts to improve and develop the federal level of the Public Procurement System by issuing numbers of methodologies and forms that aim to regulate the process of Government contracting (Standard Bidding Documents (SBDs), procurement Planning Forms, Performance Indicators, Guide of Archiving Process, and so on) [2]. The standard documents were prepared by the Government Contracts Department in the Ministry of Planning under the World Bank's supervision. The Preparation of SBDCS's forms and procedures were based on the criteria and selection methods used by FIDIC and on the World Bank's consultant selection procedures and guidelines. $\mathrm{T}$

he documents have been modified to comply with Iraqi laws and legislation. Within the year 2016, The Iraqi Government mandates the public sector's contractual bodies to apply the standard bidding documents in their governmental financed projects. Due to the novelty of the SBDCS, it has become necessary to conduct a continuous evaluation to determine the most important challenges facing its correct implementation and to measure its suitability to the reality of Iraqi projects. 


\section{Criteria for Consultant Selection}

The expertise, commitment, and personalities of construction consultants significantly impact the cost and efficiency of constructed buildings. However, when choosing professional services, it is important to consider non-price criteria for both companies and individual's consultants, which is difficult to define. As a result, clients have historically relied on long-term relationships or the recommendation from clients or co-workers [1]. In Us, the Qualifications-Based Selection (QBS) procedure was mandated by the American Contract Law Regulating Competition (the 1972 Brooks Act/Public Law 92-582) for the award of architectural and engineering services contracts involving federal funds. (SEC.904. A) of the Brooks law mandate that (The agency head shall negotiate a contract with the highest qualified firm for architectural and engineering services at compensation which the agency head determines is fair and reasonable to the Government. In making such determination, the agency head shall take into account the estimated value of the services to be rendered, the scope, complexity, and professional nature thereof). The Brooks Act's goal is to ensure that the public client chooses the most skilled design expert regardless of cost.

Regardless of the criterion on which the construction contract is awarded, Gransberg [3] found that awarding design consultant contracts to the lowest tender bid causes a condition where the incremental savings in design costs are spent during the construction phase as a result of design deficiencies. He concluded that Clients believe that the competence and previous experience of consultant companies with which they work are more important than the project's particulars in determining project progress. Additionally, further design effort was found to minimize the project's final expense from early projections by resolving development issues during the design process, where prices are small, rather than after construction has begun. Table 1 shows the criteria identified for the consultant selection in previous studies.

\section{Study Cases Analysis and Discussion}

For this study, six study cases of bidding documents for consultant acquisitions in governmental construction projects according to SBDCS were considered. The aim is to provide actual cases of the issues in the standard bidding documents for a consultancy service implementation. The selected study cases were recommended by reference [3] specialized experts in governmental contracting and construction projects, the evaluation of them was based on the required processes and information according to SBDCS, Global bank guidelines (selection and employment of consultant), Iraqi guide for the governmental contracts implementation and Iraqi instructions for governmental contracts implementation. Table 2 shows details of the selected projects and their SBDCS process description and evaluation.

Table 1. Criteria identified from previous studies.

\begin{tabular}{|c|c|c|c|c|c|c|c|c|c|c|c|c|c|c|c|c|c|c|c|c|c|}
\hline \multirow{2}{*}{$\begin{array}{c}\text { Previous } \\
\text { studies }\end{array}$} & \multicolumn{21}{|c|}{ Criteria } \\
\hline & $(1)$ & (2) & (3) & (4) & (5) & (6) & (7) & $(8)$ & (9) & $(10)$ & $(11)$ & $(12)$ & $(13)$ & (14) & (15) & (16) & (17) & $(18)$ & (19) & (20) & $(21)$ \\
\hline [5] (Nigeria) & 凶 & & 凶 & & & 凶 & 凶 & 凶 & 凶 & 凶 & 凶 & 囚 & 区 & & 凶 & & & & 区 & 凶 & \\
\hline [4] (Germany) & 凶 & $\otimes$ & & & & & & & 凶 & & 凶 & 囚 & & & & & & & 凶 & & \\
\hline [6] (KSA) & 凶 & & 曰 & & 叉 & 曰 & 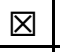 & & & & 凶 & 凶 & & & 凶 & & & 凶 & 凶 & 区 & 叉 \\
\hline [7] (Iraq) & 凶 & 凶 & & 凶 & 凶 & 凶 & 凶 & 凶 & & 凶 & 凶 & 囚 & 区 & 凶 & 凶 & 凶 & & & 凶 & 凶 & \\
\hline [8] (Egypt) & 凶 & $\otimes$ & Q & & & & & & & 凶 & 凶 & 区 & 区 & Q & & 凶 & & & 区 & & 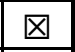 \\
\hline [9] (Turkey) & $\square$ & 凶 & Q & & Q & & Q & Q & & & 区 & & & & & & & & & & \\
\hline [1] (Sweden) & 凶 & 凶 & 凶 & & 凶 & 凶 & & 凶 & & & 凶 & 囚 & & 凶 & & 凶 & & & 凶 & 凶 & \\
\hline [10] (Gaza) & & $\otimes$ & & & Q & Q & Q & Q & & 凶 & 凶 & 区 & 凶 & & & 凶 & 区 & & & & \\
\hline [11] (USA) & & & $\square$ & & Q & Q & & Q & & 凶 & 区 & & & & & & & & & & \\
\hline [12] (Hong Kong) & 凶 & & 区 & 区 & & & & 曰 & & 凶 & 凶 & 凶 & & 凶 & & 凶 & & & 区 & & \\
\hline [13] (UK) & & $\otimes$ & & & & & & & & & 凶 & & 凶 & & 凶 & & & & 凶 & & \\
\hline
\end{tabular}


(1) Reputation and references \& claims from previous contracts

(2) Relationships with clients Compliance with demands

(3) Service fee and tender price

(4) Current commitments

(5) Type \& size of completed projects

(6) Years in business

(7) Type companies employed

(8) Prior related assignments

(9) Firm specialization

(10) Total number of technical and administrative staff

(11) Key personnel quality and experience

(12) Planning capability and achieving objects

(13) Equipment and software

(14) Cost-effectiveness and value management

(15) Number and expertise of management personnel

(16) Scheduling and time control

(17) Previous project time and cost overruns

(18) Amount and duration of insurance

(19) Work efficiency and consultant process quality

(20) Innovative capabilities

(21) Green approach pollution control

Table 2. Case studies analysis.

\begin{tabular}{|c|c|c|c|c|c|c|c|}
\hline \multirow{2}{*}{\multicolumn{2}{|c|}{ Projects information }} & \multicolumn{6}{|c|}{ Case study } \\
\hline & & 1 & 2 & 3 & 4 & 5 & 6 \\
\hline \multicolumn{2}{|c|}{ Project type } & $\begin{array}{c}\text { Infrastructure } \\
\text { for } \\
\text { transportation }\end{array}$ & Dam & Sewages & $\begin{array}{c}\text { Environmental } \\
\text { studies }\end{array}$ & Hospital & Dam \\
\hline \multicolumn{2}{|c|}{ Requires service } & $\begin{array}{c}\text { Contract } \\
\text { administration }\end{array}$ & $\begin{array}{c}\text { Feasibility } \\
\text { study }\end{array}$ & Design and audit & $\begin{array}{l}\text { Technical } \\
\text { assistance }\end{array}$ & Design & Maintenance \\
\hline \multicolumn{2}{|c|}{$\begin{array}{l}\text { Estimated cost } \\
\left(\times 10^{6}\right)\end{array}$} & Not mentioned & $\begin{array}{c}\text { Not } \\
\text { mentioned }\end{array}$ & $\begin{array}{l}\text { Audit: } 1,155 \text { ID } \\
\text { Design: } 2,610 \text { ID }\end{array}$ & 300 ID & $\begin{array}{c}\text { Not } \\
\text { mentioned }\end{array}$ & 935 ID \\
\hline \multicolumn{2}{|c|}{ Year } & Nov. 2020 & 2020 & 2019 & 2017 & 2019 & 2018 \\
\hline Process & Part & Case 1 & Case 2 & Case3 & Case4 & Case5 & Case6 \\
\hline \multirow{10}{*}{$\begin{array}{l}\text { Term of } \\
\text { reference }\end{array}$} & $\begin{array}{c}\text { Project } \\
\text { background }\end{array}$ & & & & & & \\
\hline & Project object & & & & & & \\
\hline & $\begin{array}{l}\text { Scope of the } \\
\text { required service }\end{array}$ & & & & & & \\
\hline & Work schedule & & & & & & \\
\hline & Service output & & & & & & \\
\hline & Required reports & & & & & & \\
\hline & $\begin{array}{c}\text { Team structure } \\
\text { and criteria }\end{array}$ & & & & & & \\
\hline & $\begin{array}{l}\text { The service cost } \\
\text { estimation and } \\
\text { payments details }\end{array}$ & & & & & & \\
\hline & Contract duration & & & & & & \\
\hline & $\begin{array}{l}\text { Additional data } \\
\text { and facilities }\end{array}$ & & & & & & \\
\hline \multirow{3}{*}{\begin{tabular}{c|} 
Bidding \\
announceme \\
nt
\end{tabular}} & $\begin{array}{c}\text { International } \\
\text { advertising }\end{array}$ & & & & & & \\
\hline & Local advertising & & & & & $\sqrt{ }$ & \\
\hline & Direct invitation & $\sqrt{ }$ & $\sqrt{ }$ & $\sqrt{ }$ & $\sqrt{ }$ & & $\begin{array}{l}\sqrt{ } \text { (one } \\
\text { bidder) }\end{array}$ \\
\hline \multirow{2}{*}{ Short list } & 3-6 firms & & $\sqrt{ }$ & & & & \multirow{2}{*}{ Not applied } \\
\hline & More than 6 firms & $\sqrt{ }$ & & $\sqrt{ }$ & $\sqrt{ }$ & & \\
\hline
\end{tabular}




\begin{tabular}{|c|c|c|c|c|c|c|c|}
\hline $\begin{array}{r}\text { Letter of } \\
\text { invitation }\end{array}$ & \begin{tabular}{|c|}
$\begin{array}{c}\text { Provided with all } \\
\text { required } \\
\text { information }\end{array}$ \\
\end{tabular} & & & & & & \\
\hline $\begin{array}{c}\text { Instruction } \\
\text { to } \\
\text { consultants }\end{array}$ & $\begin{array}{c}\text { Provided with all } \\
\text { required } \\
\text { information }\end{array}$ & & & & & & \\
\hline \multirow{2}{*}{$\begin{array}{c}\text { local } \\
\text { consultant } \\
\text { participant }\end{array}$} & yes & $\sqrt{ }$ & & $\sqrt{ }$ & & $\sqrt{ }$ & \\
\hline & no & & $\sqrt{ }$ & & $\sqrt{ }$ & & $\sqrt{ }$ \\
\hline \multirow{2}{*}{$\begin{array}{c}\text { Training of } \\
\text { staff }\end{array}$} & yes & & & $\sqrt{ }$ & & $\sqrt{ }$ & \\
\hline & no & $\sqrt{ }$ & $\sqrt{1}$ & & $\sqrt{ }$ & & $\sqrt{ }$ \\
\hline \multirow{3}{*}{$\begin{array}{c}\text { Type of } \\
\text { invited firm }\end{array}$} & Local & & & & & $\sqrt{ }$ & \\
\hline & International & $\sqrt{ }$ & & $\sqrt{ }$ & $\sqrt{ }$ & & $\sqrt{ }$ \\
\hline & $\begin{array}{c}\text { local and } \\
\text { international }\end{array}$ & & $\sqrt{ }$ & & & & \\
\hline \multirow{2}{*}{$\begin{array}{l}\text { Type of } \\
\text { selected } \\
\text { contract }\end{array}$} & Lump-sum & $\sqrt{ }$ & $\sqrt{ }$ & $\sqrt{ }$ & $\sqrt{ }$ & $\sqrt{ }$ & \\
\hline & Time-based & & & & & & $\sqrt{ }$ \\
\hline $\begin{array}{c}\text { Special } \\
\text { condition }\end{array}$ & $\begin{array}{c}\text { Provided with all } \\
\text { necessary } \\
\text { information }\end{array}$ & & & & & & \\
\hline \multirow{3}{*}{$\begin{array}{l}\text { Selecting } \\
\text { method }\end{array}$} & Quality and cost & $\sqrt{ }$ & $\sqrt{ }$ & $\sqrt{ }$ & $\sqrt{ }$ & $\sqrt{ }$ & $\sqrt{ }$ \\
\hline & Under least cost & & & & & & \\
\hline & $\begin{array}{c}\text { Under fixed } \\
\text { budget }\end{array}$ & & & & & & \\
\hline \multirow{2}{*}{$\begin{array}{c}\text { trained } \\
\text { Contractual } \\
\text { stuff }\end{array}$} & yes & & & $\sqrt{ }$ & & & \\
\hline & No & $\sqrt{ }$ & $\sqrt{ }$ & & $\sqrt{ }$ & $\sqrt{ }$ & $\sqrt{ }$ \\
\hline \multirow{2}{*}{\begin{tabular}{|c|} 
In contact \\
with \\
MOP/GGC/ \\
help desk \\
office \\
\end{tabular}} & yes & & $\sqrt{ }$ & $\sqrt{ }$ & & $\sqrt{ }$ & $\sqrt{ }$ \\
\hline & no & $\sqrt{ }$ & & & $\sqrt{ }$ & & \\
\hline \multirow{2}{*}{$\begin{array}{c}\text { THE SBDCS } \\
\text { preparations } \\
\text { were in }\end{array}$} & $\begin{array}{c}\text { Headquarter } \\
\text { contract } \\
\text { department }\end{array}$ & & & $\sqrt{ }$ & & & \\
\hline & \begin{tabular}{|c|}
$\begin{array}{c}\text { Contracts Section } \\
\text { of Project } \\
\text { Department }\end{array}$ \\
\end{tabular} & $\sqrt{ }$ & $\sqrt{ }$ & $\sqrt{ }$ & $\sqrt{ }$ & $\sqrt{ }$ & $\sqrt{ }$ \\
\hline \multicolumn{2}{|c|}{ Responsive invited consultant } & $\begin{array}{c}2 \text { with re- } \\
\text { invited }\end{array}$ & 3 & 7 & $\begin{array}{c}\text { Re-announced } \\
\text { twice }\end{array}$ & 3 & $\begin{array}{l}1 \text { single } \\
\text { source }\end{array}$ \\
\hline \multirow[b]{2}{*}{$\begin{array}{l}\text { Time for } \\
\text { consultant } \\
\text { evaluation }\end{array}$} & \begin{tabular}{|c|} 
Within 3 months \\
that start from last \\
day of receiving \\
consultant offers \\
\end{tabular} & $\begin{array}{c}\text { The project } \\
\text { has been } \\
\text { suspended at } \\
\text { the beginning }\end{array}$ & & & The project has & & \\
\hline & Exceed 3 months & $\begin{array}{l}\text { of } 2021 \text { before } \\
\text { the evaluation } \\
\text { process } \\
\text { (no budget } \\
\text { was allocated } \\
\text { for it in } 2021 \\
\text { investment } \\
\text { budget) }\end{array}$ & $\sqrt{ }$ & $\sqrt{ }$ & $\begin{array}{c}\text { been suspended } \\
\text { before the } \\
\text { evaluation } \\
\text { process } \\
\text { (no budget was } \\
\text { allocated it) }\end{array}$ & $\sqrt{ }$ & $\begin{array}{c}\text { Not applied/ } \\
\text { Single source } \\
\text { selection }\end{array}$ \\
\hline \multirow{2}{*}{\begin{tabular}{|c|}
$\begin{array}{c}\text { implemented } \\
\text { SBDCS } \\
\text { before this } \\
\text { project }\end{array}$ \\
\cline { 2 - 2 }
\end{tabular}} & Yes & & $\sqrt{ }$ & & & & $\sqrt{ }$ \\
\hline & No & $\sqrt{ }$ & & $\sqrt{ }$ & $\sqrt{ }$ & $\sqrt{ }$ & \\
\hline
\end{tabular}

Where: 
Refer to well-provided details

Refer to medium

Refer to poor

\section{Analysis and Discussion}

1. Five out of six contractual entities haven't been trained on applying the SBDCS. The lack of trained staff to use the document led to insufficient provided information when preparing the terms of reference, instructions to the consultants, the required team's structure and specialization, the special conditions of the contract, and the improper shortlisting. This led to a decrease in the number of responsive consultants, especially the highly experienced ones.

2. Five out of six projects use the direct invitation method instead of announcing to bid. This didn't give the opportunities for all consultants to express their desire to participate in the bid, especially in projects that do not require specific specializations, and the advertising method can be used in it.

3. The neglect of the local engineering consultant's participation in the governmental construction projects led to the deterioration of the local engineering consultancy offices.

4. The contracting bodies take a long time in the consultants' evaluation process as a result of the low experience of the contractual department's staff in the evaluation process, according to SBDCS.

5. Weak communication between contracting departments of the governmental entities and the Ministry of Planning's General Governmental Contract Department / help desk office as a result of routine procedures and delay in response.

6. The consultant selection method, according to SBDCS, is not compatible with the single source invitation when a specific consultant is needed for a specialized task, which creates confusion for the contract department regarding the consultants' instructions and method of selection as in Case Study No. 6. A single source selection should be added to the SBDCS selection methods.

7. Case Study No.3 has the best documents' assessment, which affected attracting more consultants, as it achieved the highest percentage of consultants' responses ( 7 out of 11 consultants).

8. The recent economic crises led to a decrease in the budget financial allocation for the investment projects, which led to cancel the budget allocation for many investment projects and their suspension, as in projects 2 and 4.

\section{Developing an Evaluation System}

The researchers proposed an evaluation system that helps the contractual entities enhance consultant evaluation efficiency according to SBDCS; the proposed system performs the consultant evaluation process and selects the best consultant according to SBDCS criteria. The computer model was created by Visual Studio 2019 computer's program using the C\# language; the program was developed to conduct a fast and accurate evaluation process. The assessor doesn't need to be trained to use the program. Each evaluator enters the weighted evaluation percentages for each criterion according to the consultant's competence, and the model selects the best consultant according to the following steps:

1. Evaluating the technical degree of the consultant separately for each assessor.

2. Calculating the final technical grade for each bid.

3. Comparing the final technical grade for each bid with the required success degree.

4. Display of bids that passes the required technical degree.

5. 5-Conducting the financial evaluation based on the selected method. (Quality and cost method, estimated budget method, least cost method)

6. Display the final degree of bidders and determining the winning bidder. 
The program language display is Arabic (The official language in Iraq). Figure 1 displays the flow chart of constructed program. Figures 2 to 9 display the mean steps of program.

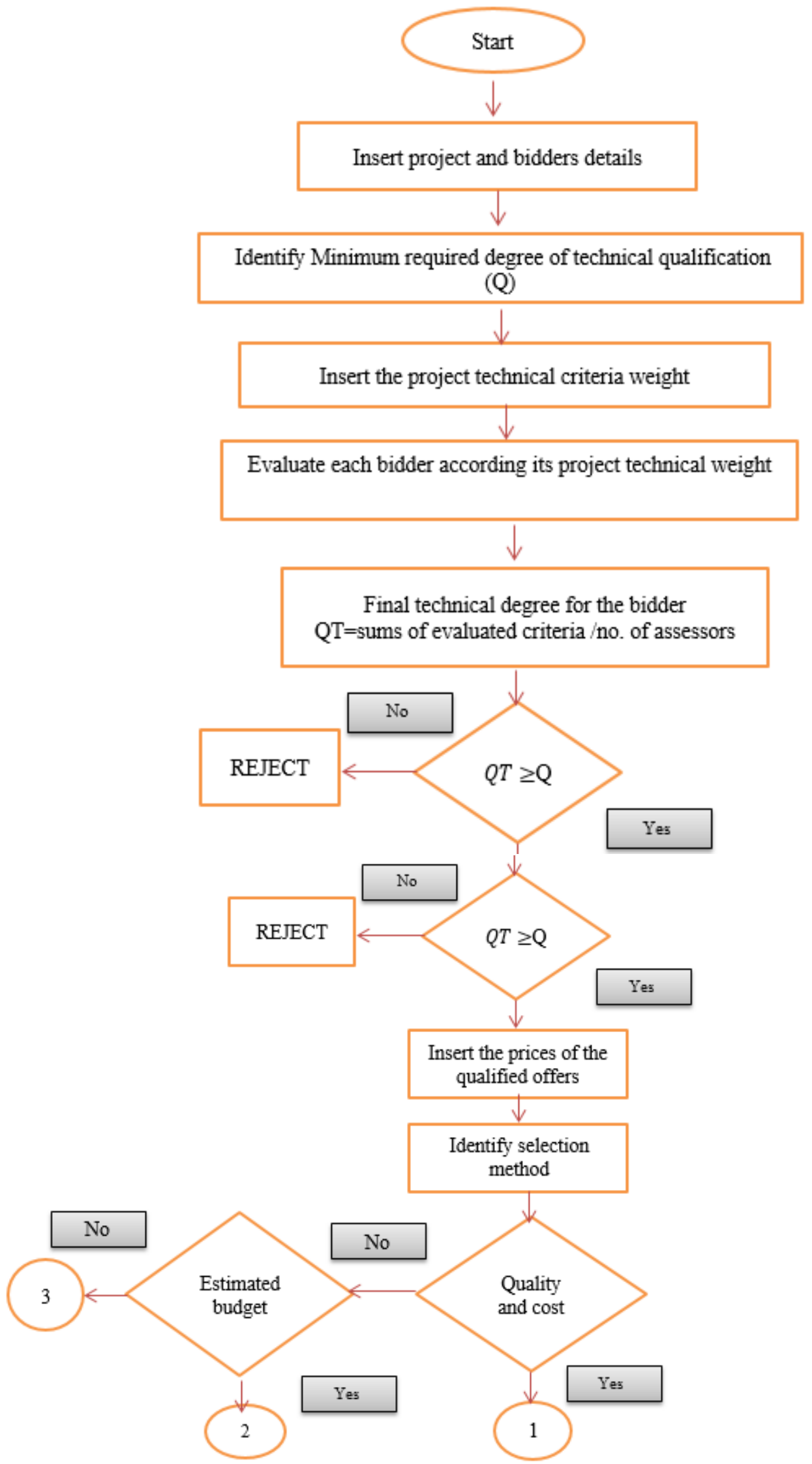

Figure 1. Flow chart of the proposed program. 


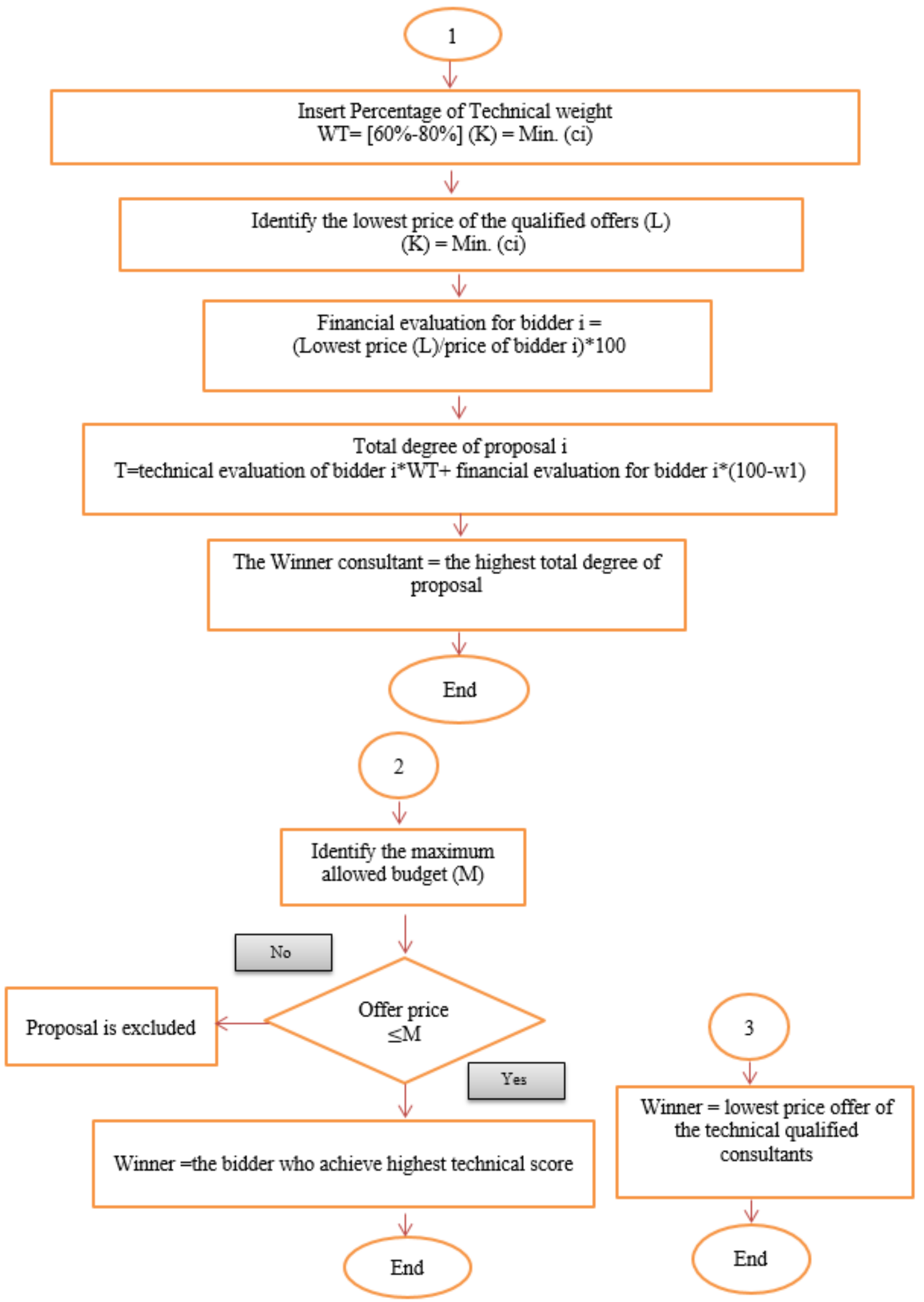

Figure 1. Continued. 


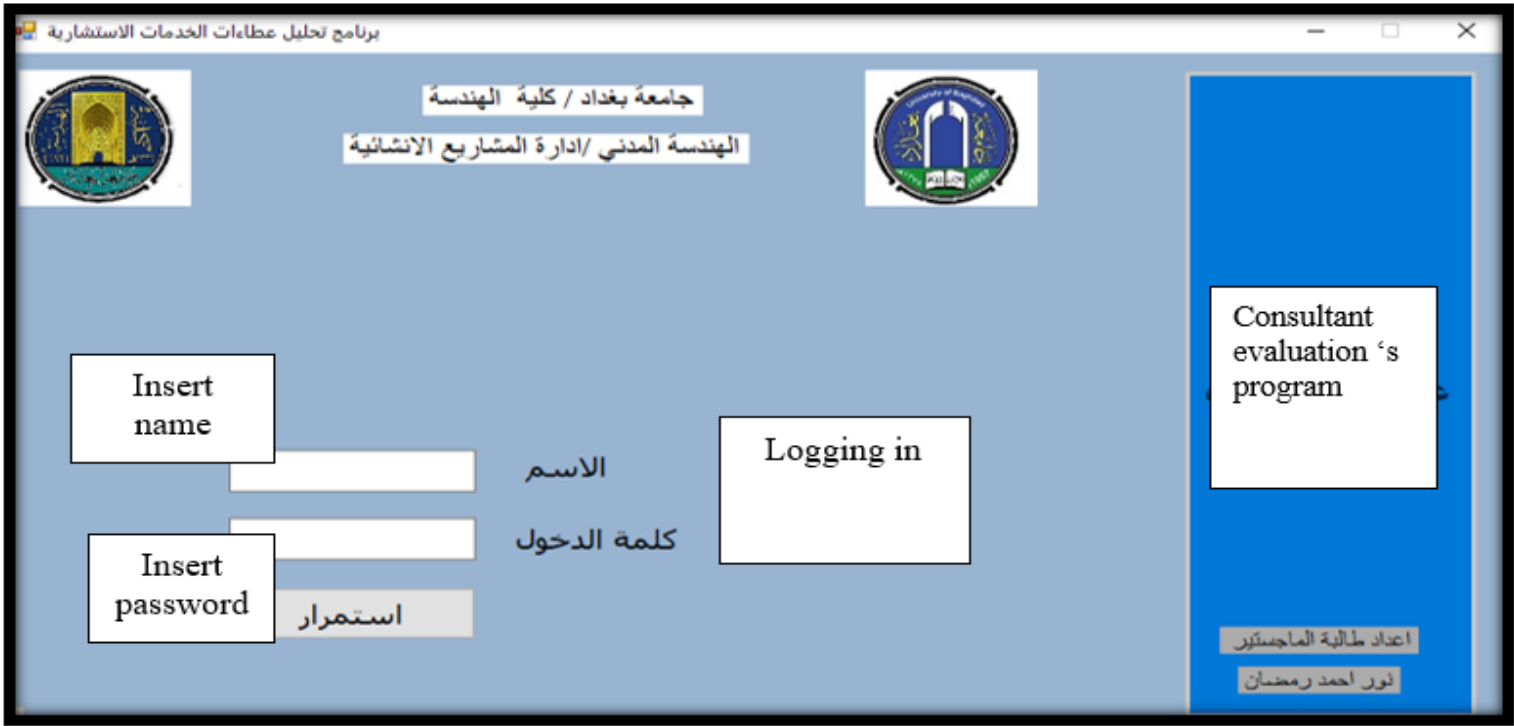

Figure 2. Log in menu: name and password for authenticated user.

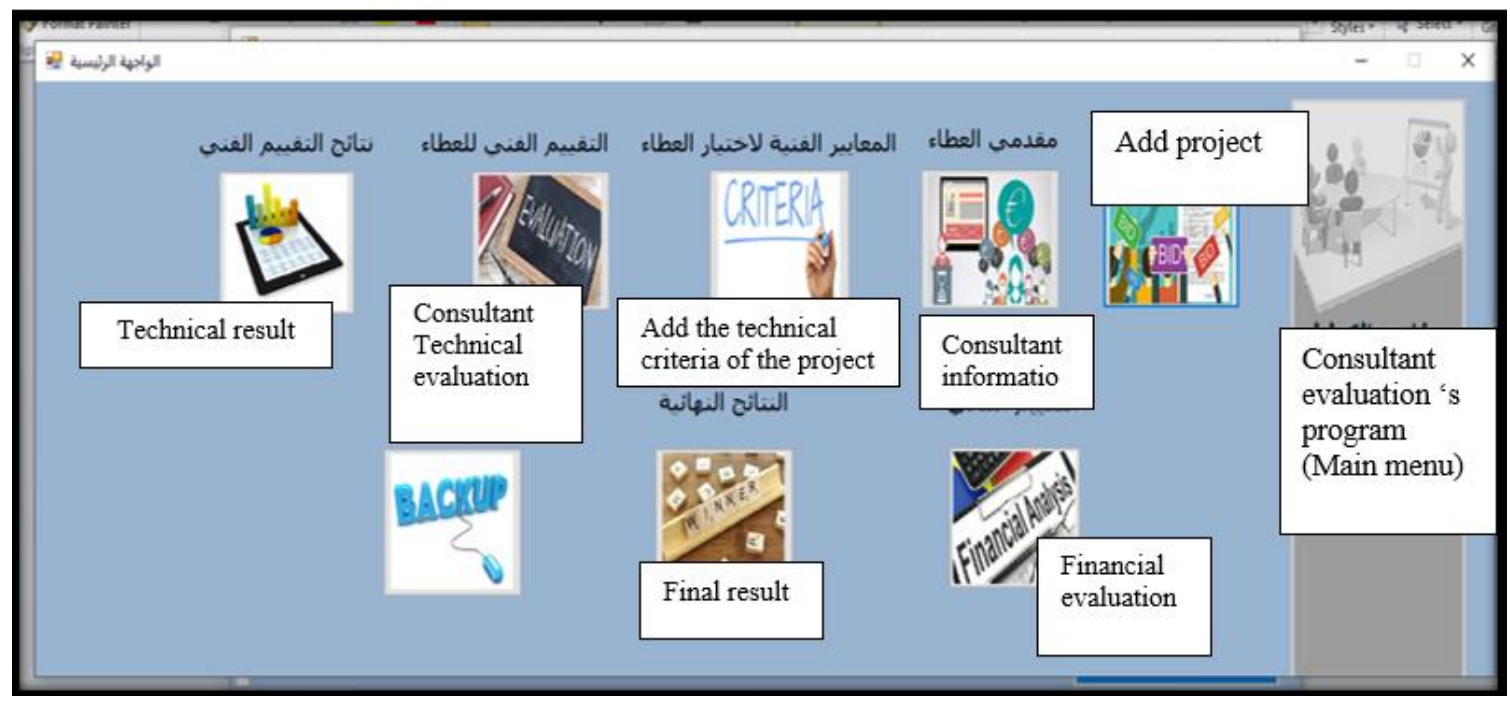

Figure 3. Main list menu.

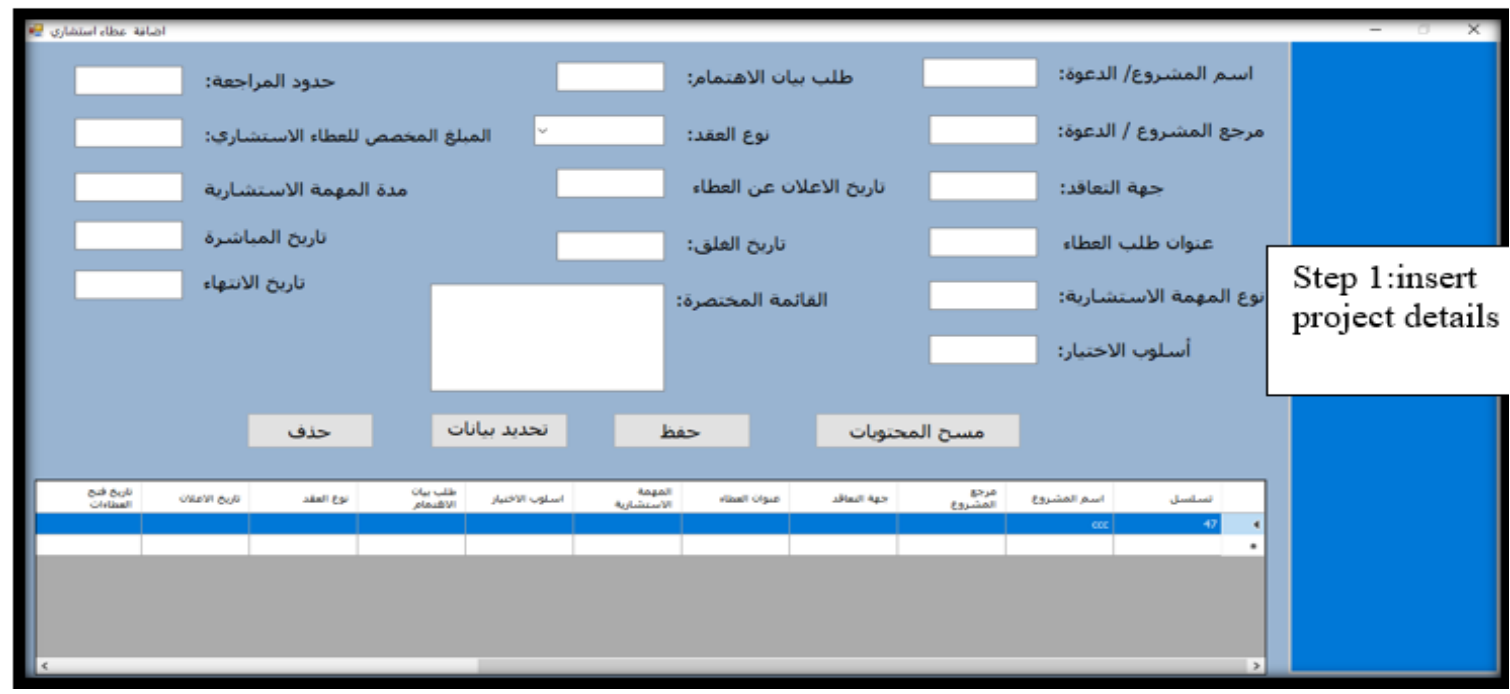

Figure 4. Project information details' menu. 


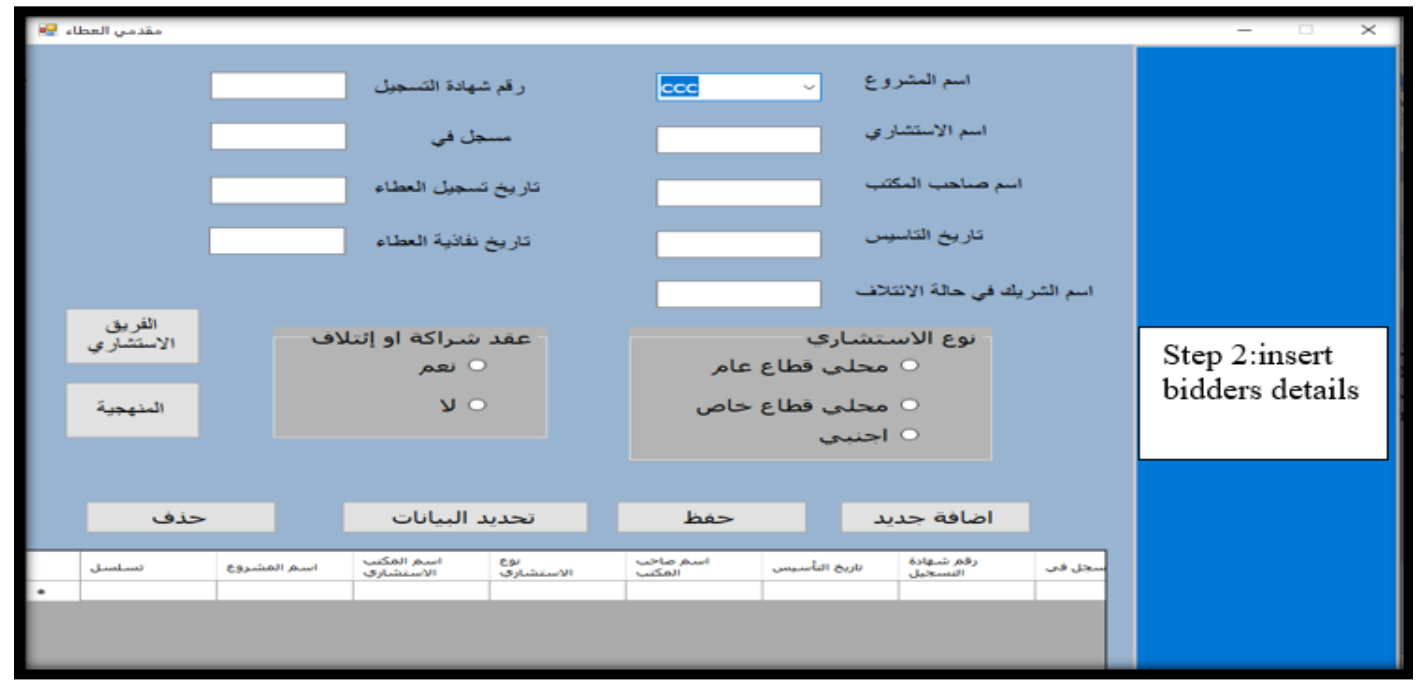

Figure 5. Bidders' information details' menu.

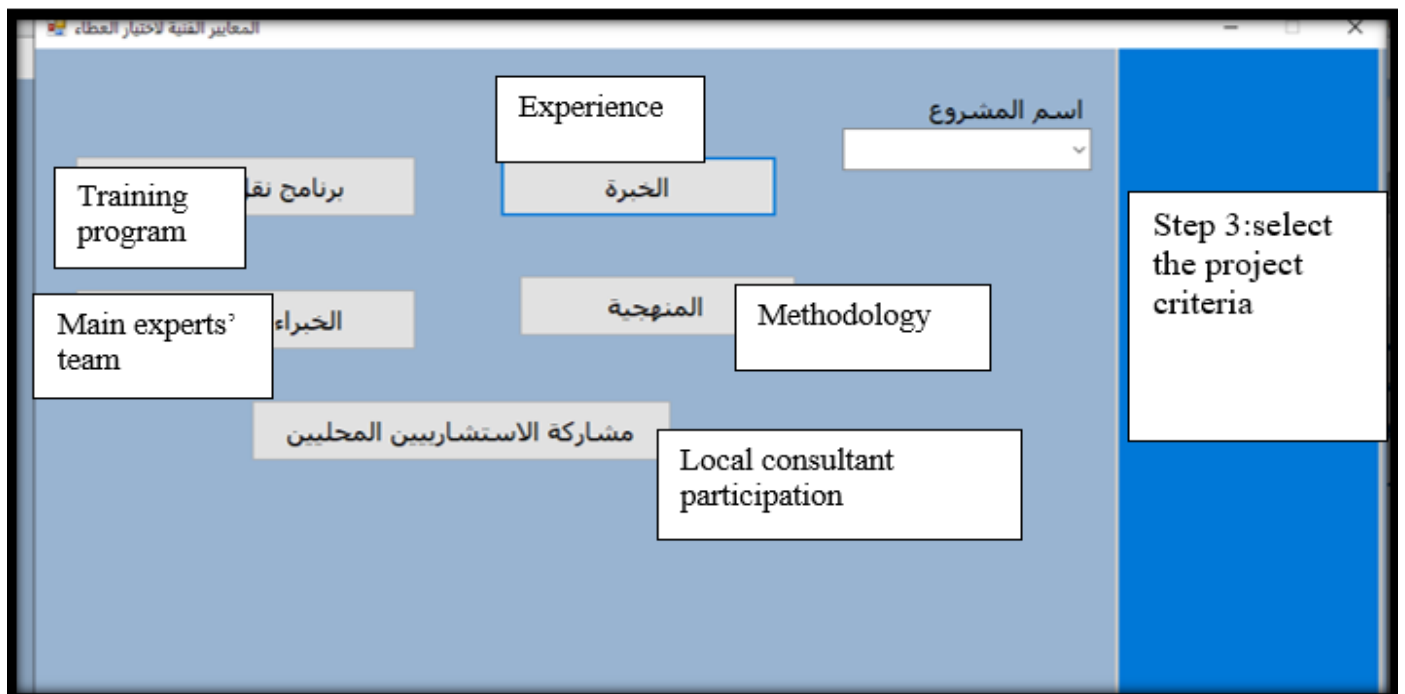

Figure 6. Technical criteria menu, select the Project name and press each icon to add criteria weight.

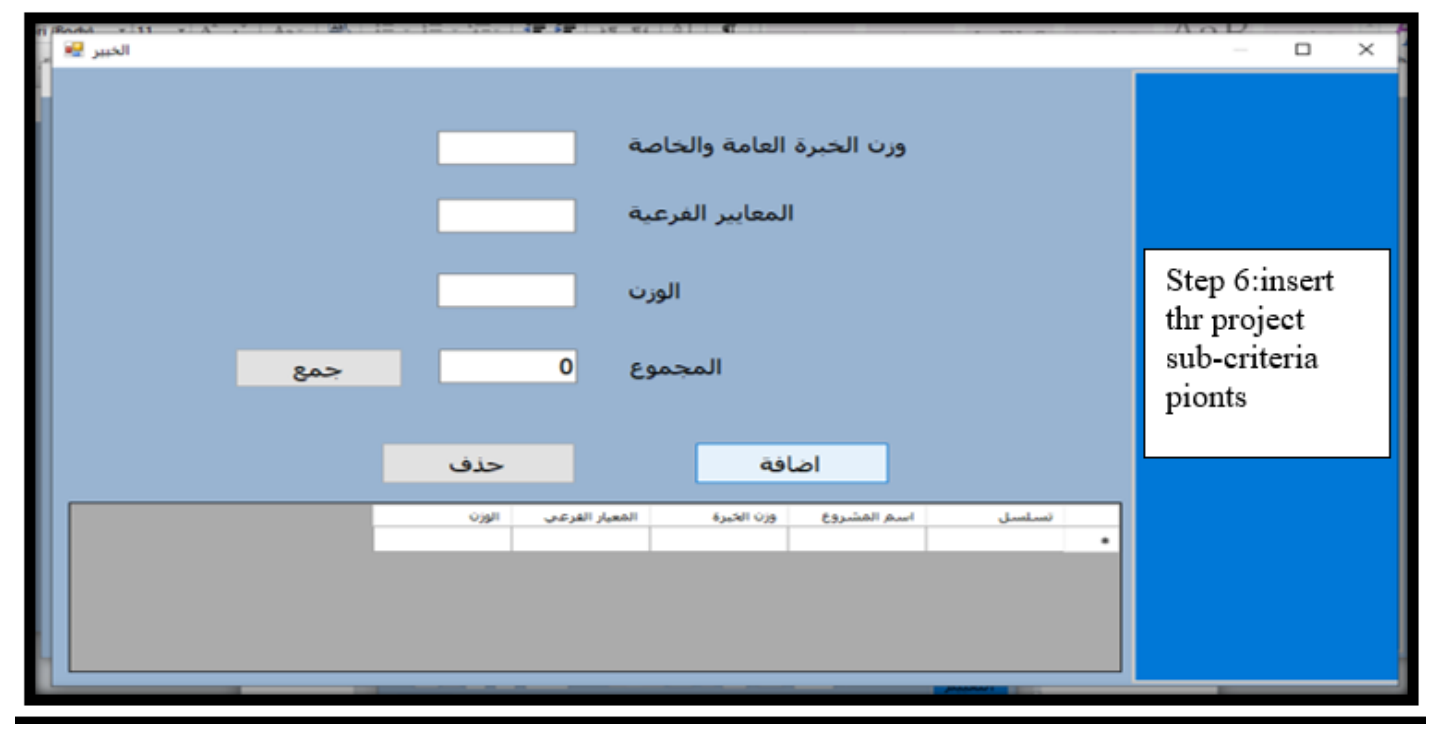

Figure 7. menu of inserting the technical sub- criteria weight. 


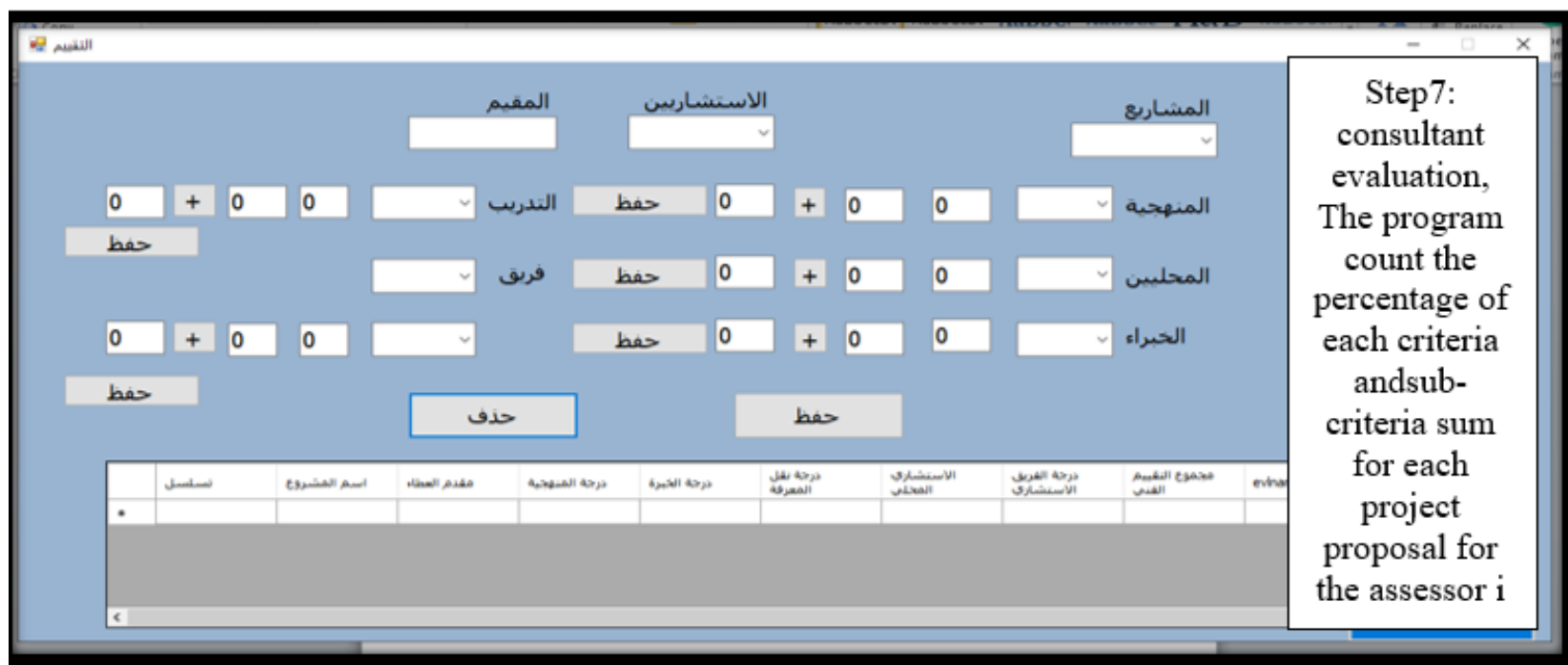

Figure 8. Technical evaluation's menu.

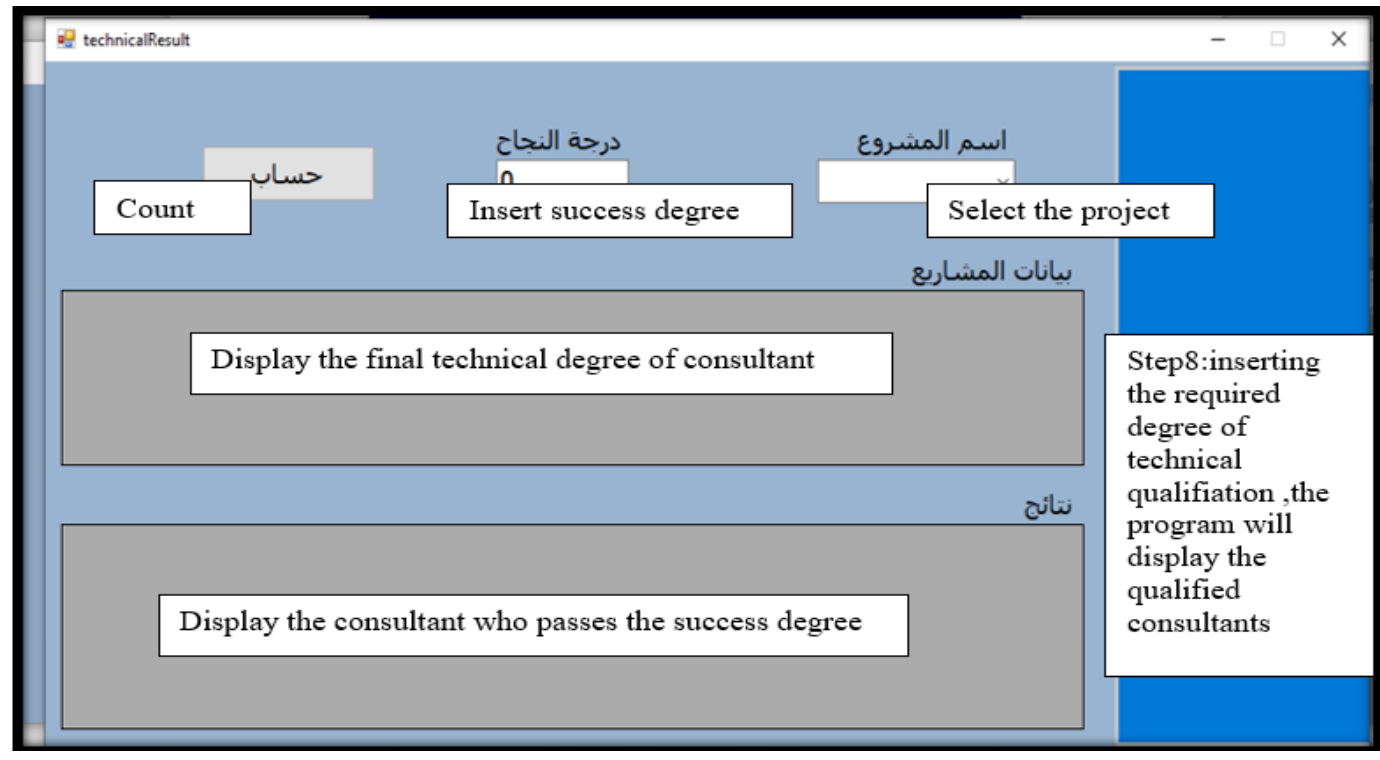

Figure 9. Menu of technical results.

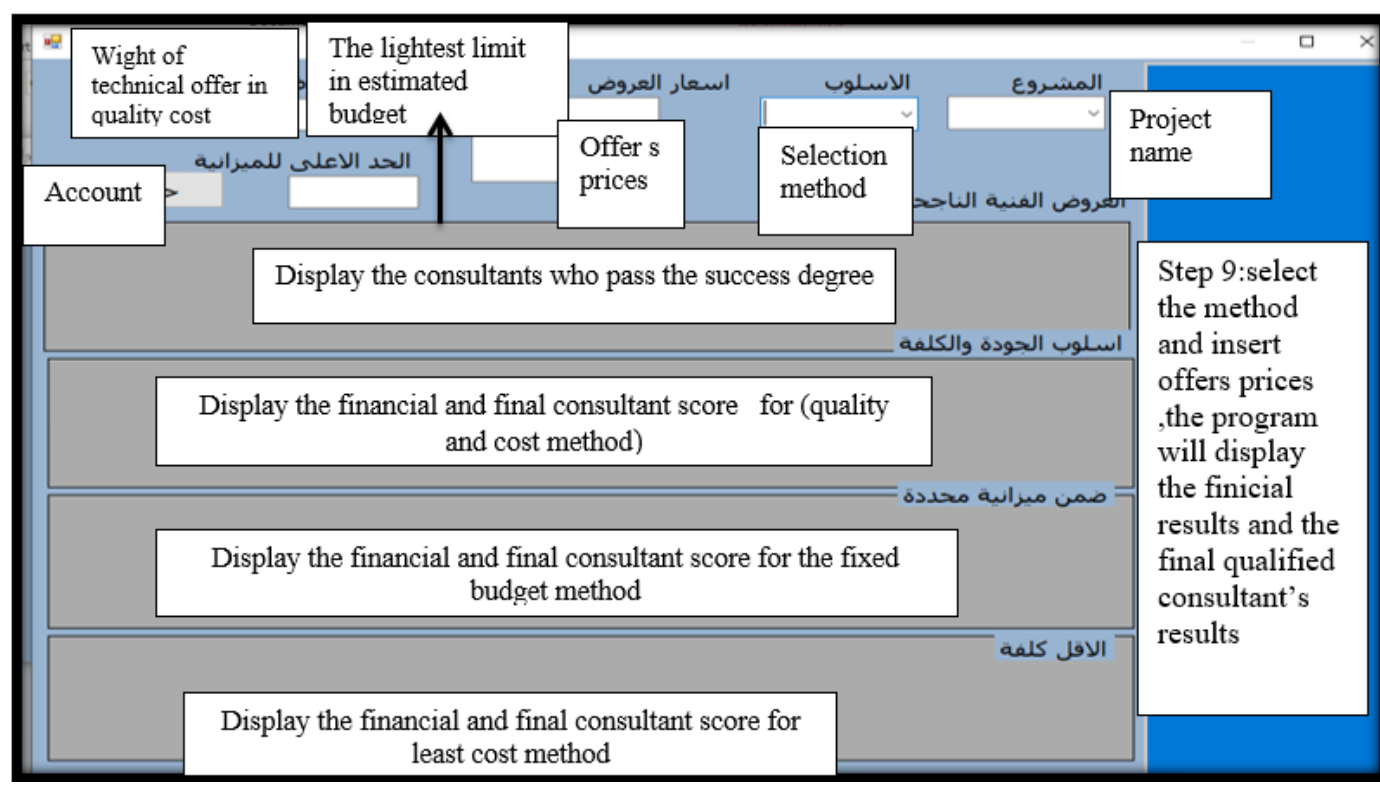

Figure 10. Menu of financial evaluation and final results. 


\section{Conclusions}

The provided information influences the acquisition of qualified consultants in the construction project in the bidding documents. The cases study's analysis indicated the importance of terms of reference (TOR) to provide sufficient information for the invited consultants. The well-prepared project's TOR leads to draw the attention of the high experienced consultancy firm to bid and save the waste of time due to re-announcing or re-inviting as a result of insufficient numbers of interested bidders. Most of projects' TOR in the cases study were prepared by unqualified staff. It should emphasize the employment of a well-trained and specialized staff for the project's TOR preparation. 5 out of 6 contractual departments in the cases study sent the request of invitation directly to consultants without publishing or sending the letter of invitation to ensure their desire to participate in the bidding. This confusion happened due to the lack of unified instructions between the SBDCS and Iraqi instructions for governmental contracts implementation. The documents' instructions regarding the consultancy service should be reviewed and unified.

Most of the contractual bodies neglect the local consultant participation in international contracting. The embedded of local consultant participation in international consultant bidding evaluation criteria improves the local consultants' experience. The contractual bodies of all government institutions are lacking to specialized experience in managing construction contracts. In the previous regime, all construction contracts were made exclusively by the Ministry of Construction and Works. After 2003, each governmental entity became responsible for managing and implementing its construction and investment projects with the conditions of Job instability resulting from political succession in position occupying.

\section{Acknowledgments}

This study was conducted with the cooperation and support of the Ministry of Water Recourses, Ministry of Planning, Ministry of Transportation, and Mayoralty of Baghdad.

\section{References}

[1] Sporrong, J., 2011. Criteria in consultant selection: public procurement of architectural and engineering services. Australasian Journal of Construction Economics and Building, The, 11(4), pp.59-76.

[2] Hasan, S.A. and Mohammed, S.R., 2020, August. An Evaluation of Barriers obstructing the Applicability of Standard Bidding Documents (SBDs) in Public Procurement of Iraq. In IOP Conference Series: Materials Science and Engineering (Vol. 901, No. 1, p. 012027). IOP Publishing.

[3] Gransberg, D.D., 2020. Accelerating Project Delivery through Early Contractor Involvement, NAC Executive Insights, National Academy of Construction, EI 1.7.

[4] Nissen, V. ed., 2017. Digital transformation of the consulting industry: extending the traditional delivery model. Springer.

[5] Ogbu, Ch. And Omogiate, M, 2020. Criteria for selection of consultants for tertiary institution construction projects in Nigeria, The Quantity Surveyor.

[6] Assaf, S., Hassanain, M.A., Hadidi, L. and Amman, A., 2018. A systematic approach for the selection of the architect/engineer professional in construction projects. Architecture, Civil Engineering, Environment, 10(4).

[7] Altaie, M., 2017. Optimal indicators to select the engineering consultancy office for higher education institutions in Iraq. Journal of Engineering, 9(23), pp.45-63. (In Arabic).

[8] Elbarkouky, M., El-Deeb, M. and Marzouk, M., 2013. An AHP approach for consultant selection in Real Estate mega projects in the Middle East. In Annual Conference of the Canadian Society for Civil Engineering (pp. 731-742). 
[9] Vayvay, O., Ozcan, Y. and Cruz-Cunha, M.M., 2012. ERP consultant selection problem using AHP, fuzzy AHP and ANP: A case study in Turkey. E3 Journal of Business Management and Economics, 3(3), pp.106-117.

[10] AL Shabaky, A. 2008. Consultancy Offices Selection Based on the Analytic Hierarchy Process According To Decision Makers In Gaza StriP" Master Thesis. Islamic University, Gaza. (In Arabic).

[11] Christodoulou, S., Griffis, F.H., Barrett, L. and Okungbowa, M., 2004. Qualifications-based selection of professional A/E services. Journal of Management in Engineering, 20(2), pp.34-41.

[12] Cheung, F.K., Kuen, J.L.F. and Skitmore, M., 2002. Multi-criteria evaluation model for the selection of architectural consultants. Construction Management \& Economics, 20(7), pp.569580 .

[13] Hoxley, M., 2000. Are competitive fee tendering and construction professional service quality mutually exclusive? Construction Management and Economics, 18(5), pp.599-605. 